\title{
A STUDY OF UNETHICAL PRACTICES IN THE CONSTRUCTION INDUSTRY AND POTENTIAL PREVENTIVE MEASURES
}

\author{
R. K. Shah ${ }^{1}$ and M. Alotaibi ${ }^{2}$ \\ ${ }^{1}$ Senior Lecturer in Construction Management and Civil Engineering, Department of the Built Environment, \\ Faculty of Engineering and Technology, Liverpool John Moores University, Liverpool, L3 3AF, UK.
}

Email Address: r.shah@ljmu.ac.uk

\begin{abstract}
The conflict of interest amongst the professionals like client and contractor project managers, site engineers, quantity surveyors and designers/architects play crucial roles for the unethical practices and consequently these practices have adverse impact on the product quality, faith of clients and investors' confidence in the construction industry. Hence, this research is aimed at examining the common forms of unethical practices among professionals in the construction industry as well as uncovering the factors that have encouraged these practices. This study depends on the questionnaire survey amongst professionals of the construction industry. The survey is conducted to recognise the view of key stakeholders from different perspectives of the affected parties on the concept of business ethics in the building and construction industry, which has key contribution on the national economic growth of the developing countries. The survey concludes that untimely legal action including changing project manager'sresponsibility and delays in payment processes are key ethical practices from owner/client aspect, while contractor's unethical practices are under bidding, bid cutting and shopping, bid rigging and over billing. But from the consultant aspect; lack of supervision, poor monitoring and taking bribes under different pretend are found to be the encouraging factors for unethical conducts in the construction industry. It is also found thataccepting the bribes, gifts and conflicts of interest are the most common forms of unethical practices. The findings from the study are expected to help as an important eye opener to policy makers and regulatory agencies in detecting and preventing unethical practices. In conclusion, avoiding the conflict of interest and promoting the ethic codes to professionals will help to restore the investor and people confidence, faith of the clients and improve the quality of buildings and infrastructures. The study recommends that promoting awareness regarding the values of ethical behaviour at different forum and ensuring the effective punishment for unethical activities at different stages of project life cycle might reduce the unethical practices in the construction industry.
\end{abstract}

Key words: Bribe, Conflict of Interest, Client, Consultant, Contractor, Construction Industry, Gift, Profession, Project manager, Unethical practices

\section{Introduction}

The construction industry is a challenging and demanding business sector. However, ethical practice in the building and construction industry is the vital importance in the same way to other disciplines. As a highly debated topic, it is understood that unethical practice ranks top among the most serious ills affecting the building and construction industry. The construction industry faces with some ethical issues that are comprised of but are not restricted to: conflict of interest, inflation of bills, professional incompetence, poor work delivery, fraud, bribery, professional misconduct, intimidation and kickbacks among several other evils. The consequences of these unethical behaviours in the industry of construction can lead to confidence reduction in the profession, continuous insecure practices that 
risk lives and property, loss of income by clients and governments, needless and baseless expenditures that raise levels of poverty and reduce the quality of life amongst other things.

There are several past studies conducted about ethics and unethical practices. For example, Alsweity (2013), Hamzah et al (2010) and Hassim et al (2010) point out that the construction industry makes a considerable input to the economic development; advancement of each and every nationand makes this considerable input regardless of the development level of the said nation. The authors further indicate that this industry, apart from making such huge inputs to the economic development and progress, also offers employment of up to $10 \%$ of the total labour force including specialised professionals, skilled and semi-skilled labourers. The construction industry is a key economic engine that stimulates the economy of any country. However, the construction sector experiences many moral challenges connected to behaviours that are comprised of bid shopping, unreliable contractors, lying, claim games, conflicts of interest, payment games, threats, fraud, collusion and professional negligence (Ho, 2011). Issues of ethics in the construction industry sectors should be viewed as something of interest and as a result, it will assist to dismiss the impression that issues like those are less important or disconnected from the sector of construction (Sinha et al, 2004). Therefore, in the early stage to design, construction and delivery stage of the project, numerous factors that rely on the levels of values as well as moral terms like team ethics, personal ethics, and global responsibility should be considered. This is because all pertinent principles, which are indirectly and directly altered by the project and its background, will result to obtain advantages from the whole value supervision of the projects (Mason, 2009).

The construction project achievement chiefly relies on the conduct of the people taking part in the project from the early start to completion stages (Al-sweity, 2013). Nevertheless, there are thousands of grievances emerging every other day of different types and degree concerning operations in the industry of construction. The ethical practices within the industry as well as the critical stakeholders should be instilled and imposed. Yet, this enforcement must be founded on true and valuable comprehension on the nature, inspiration and demonstration of unethical practices if any needed results are to be assured. There exists a conflict of interest amongst the key parties such as engineer, owner and contractor. All signs show that the construction industry is required more ethical practice than any other time, but the misconduct of professionals has risen and there is a huge discord between real conduct of professionals and the moral responsibilities. This study seeks to examine the ethical issues in sector of construction and offer an image concerning unethical circumstances in the construction industry. Hence, this study focuses on analysing the unethical behaviours and suggesting the preventive measures.

\section{Literature review}

The expert ethics issues in construction affect a broad range of people. The department of public works, local authorities, customer organizations, suppliers, contractors, consultants, users of public infrastructure and home buyers are all in the range of expert ethics. Those stated have their individual inputs concerning the issues in hand and integrity issues in the construction industry (Hamzah et al, 2010). In the business development, setting morals is a strategy for giving ones best to ensure that the hobbies of the customer are suitably encouraged (Oyewobi et al, 2011). 


\subsection{Professional ethics in construction industry}

Wulf (2004) indicated fresh ethical matters are ones for the job instead of the ones for the person. The profession matters are known as macro ethical questions contrary to those for the individual, which are known as micro ethical questions. The profession ought to have a high level of control to operate its professional matters without unnecessary impact from other careers (Ogachi, 2011). Sinha et al (2004) indicated that expert ethics can differ from universal ethics, to the level that professional ethics ought to consider:

Relations between clients and practicing professionals

1. Relations between the society in general and the profession

2. Relations amongst professionals

3. Relations between worker and employer

4. Specialized technical details of the profession.

Mason (2009) indicated that any authentic career spirit cannot be attained without an element of ethics. According to UN (2006) ethical conduct's expert standards, irrespective of the organisation, have made the following distinctive characteristics and commitments to:

- Act honourably in all work aspects and professional action.

- Conduct oneself in such a way as to uphold confidence and trust in the integrity of the acquisition procedure.

- Keep away from "clever" activities planned to take unnecessary advantage of others.

- Maintain the standards and policies of the organization and all pertinent legislation.

- $\quad$ Avoid conflicts of interest.

In a development foundation, moral behaviour might be measured by the level of uprightness and reliability with which people and organisations do their business (Mason, 2009). In this regard, the next section discusses the unethical behaviours and practices happening in the construction industry.

\subsection{Unethical behaviour in the construction industry}

There is an increasing agreement in and out of the industry of construction, that corruptions as well as other unethical conducts are prevalent in the industry. Issues of ethics in the construction sector ought to be viewed as something of importance; it will assist to dismiss the ideas that matters like those are less vital to the industry of construction (Sinha et al, 2004). There are two assertions for the assumption that the ethical issues of professionals in the modern world are not mainly because of lack of knowledge. The first thing is that in the unofficial dialogue between unethical activity victims and the professional actors, the accused professional hardly ever takes the solid position that there is nothing as professional ethical duties. The duty here is intricate and ethical problems in this scenario ought to be taken into consideration (Uff, 2003). Among the most prevalent unethical behaviours in business is corruption, defined as: "the giving of some good, money or service to a suitable individual for the aim of obtaining an advantaged and positive thought (or acquisition) of one's corporate project or product" (Vee and Skitmore, 2003).

Other regularly reported untrustworthy practices are associated with misrepresentation, carelessness and break of certainty. Deceptive natures, sharp practices, dishonesty, or break of certainty, whereby 
it tries to get some exploitative and out of line favourable position, is the meaning of the unscrupulous routine of extortion (Vee and Skitmore, 2003). It is said the dishonest behaviour does not eventuate from an individual's childhood, but rather it is a piece of the strategy of learning reasonable business or being brought into the practice (Vee and Skitmore, 2003). Olusegun et al (2011) demonstrated that there is unlawfully consumed in pay off and violation to administration authorities in Government workplaces amid the grant of agreement, execution and in addition instalments. Patrick (2006) expressed that debasement can happen in various structures and different courses and at any stage of the project amid the construction venture life cycle.A study done by (Vee and Skitmore, 2003; Pearl et al, 2007) in Australia exposed that there are many kinds of ethical dilemmas and unethical practices in the construction industry like negligence, corruption, bribery, bid cutting, under bidding, cover pricing, front loading, collusive tendering, bid shopping, and withdrawal of tender. Moreover, they also classified these unethical practices into four universal kinds of actions known as conflicts of interest and they are: 1) unfair conduct, 2) fraud, 3) collusion, and 4) bribery.

Construction engineering expert witness Paul Gogulski (2014) indicated that owners in the Middle East are known to be customarily late in payment, resulting to substantial bankruptcy of contractors. A questionnaire study conducted in USA amongst the construction managers, architects, contractors, and subcontractors and representatives of the industry revealed that over 80 percent of respondents have seen untrustworthy behaviour in the construction industry. Offered hones, especially invert barters and offer shopping, got solid remarks in this review. The lion's share saw the need for everyone to have and impart moral codes to specialists however, not many practice this procedure.

A survey in Australia was conducted by Vee of and Skitmore (2003) amongst the project supervisors, building contractual workers and engineers on the range of moral issues encompassing the industry of construction and found that $90 \%$ subscribed to an expert Code of Ethics, $45 \%$ had an Ethical Code of conduct in their associations while $84 \%$ considered great moral conduct to be a basic hierarchical goal. Ninety-three percent of the members concurred that "Business Ethics" should be administered by "Individual Ethics", with 84 percent of the members demonstrating that a parity of both the prerequisites of the client and the impact on people in general should be kept up. No members saw any instances of businesses attempting to compel their labourers to join in and unscrupulous conduct. Nevertheless, every one of the members had encountered or seen some level of dishonest conduct. Eighty-one percent as unjustifiable conduct, carelessness 67 percent, irreconcilable situation 48 percent, tricky tendering 44 percent, extortion 35 percent, secrecy and legitimacy break 32 percent, pay-off 26 percent and infringement of ecological morals 20 percent (Vee of and Skitmore (2003).

A study about perception of American construction companies concerning corruption and unscrupulous business practices in worldwide construction had been done by Azhar et al (2011) and theyexposed that that debasement and deceptive business practices have marginally decreased in the last five years, due to taking after strict codes of morals by a few major universal temporary workers. In the same country Ray et al. (1999) did a poll study and they found that the dominant part organisations back the utilisation of code and with the right of withdrawal of delicate and declined spread valuing, offer shopping, and union investment in tendering.

Moreover, an exploration was done by Rahman (2008) and uncovered that the most well-known parts of dishonest conduct that are experienced by the experts are cordiality, blessings, actuations, rewards, security of the earth, wellbeing and wellbeing and in addition political and social behaviour. Then again, self-restraint, trust, obligation, interchanges, uprightness, certain identity attributes, genuineness and responsibility are the most essential qualities that a moral expert should have. 
Tendering methodology is one of basic techniques in construction industry that arrangement with moral issues shifting from the expenses caused by inadequate tenderers, reasonable tendering practices and divulgence rights to the irreconcilable situations revelation (Ray et al, 1999 and Uff, 2003).

Furthermore, Ehsan et al (2009) deals with the ethical issues existing in the Pakistan construction sector through a comprehensive research done through questionnaires, telephonic surveys and interviews with different stakeholders. According to the research, there is no single person in the industry of construction who had not faced some level of unethical behaviour. Through undertaking work past ability 15 percent, pay off 20 percent, bias 30 percent, uncalled for behaviour 30 percent, strict principles 18 percent and superseding of review technique over contracting strategy 35 percent. Political defilement and remuneration is being managed directly by various business gatherings and expert social orders far and wide. Past researchers such as Azhar et al (2011), Olusegun et al (2011), Vee andSkitmore (2003), and Degn and Miller (2003) suggested that the degenerate and dishonest practices in the construction industry can take different forms but the following are the most widely recognised unethical practices:

1. Bribery: Non-money or money support to get something consequently

2. Fraud: Deceit to obtain financial or other advantages

3. Extortion: A type of blackmail whereby one party threatens the other party of adverse consequences unless the other party meets listed demands.

4. Bid Rigging: Unlawful conspiracy whereby competitors join to falsely raise the prices of a bid.

5. Overbilling: Increasing unit prices for activities that are planned to occur earlier in the project to raise the cash flow.

6. Change Order Games: Presenting a low bid in order to win the project and later on get back the profit by presenting change orders.

7. Claim Games: Making additional earnings through presenting false claims.

8. Money Laundering: Moving assets or cash acquired by criminal activity from one place to another, to hide the source of finances.

9. Cover pricing: Happens when a bidder only wants to be seen to take part but never wants to win the occupation so asks for an adversary for a reasonable "spread cost" and shows it as a real offer. An organisation may have decent reasons to ask for at a spread cost so it can present a solid offer including that: it might get dropped from a delicate run-down in the event that it doesn't join in, or it might need capacity for the employment yet need to pull in future occupation from the same important.

\subsection{Ethics in Construction Project Management}

In undertaking administration, moral is an imperative issue and has a fundamental part in venture's prosperity. Venture acquisition is one of the territories that should be centred around. It is one of the key regions in undertaking administration that has prompted moral practices in the venture usage (Hassim et al, 2010). The activity of obtainment takes after certain steps. These strides should be seen so as to ensure that every one of the partners in the acquirement exercise get just treatment. The strides include; anticipating the required gain over a particular period, deciding the outcome of things, distinguishing details of acquirement, deciding acquisition processes, sourcing offers, evaluation of offers, initiation of agreements, post capability, contract execution and administration, responsibility 
and record keeping instalment and post contract execution (Eyaa and Oluka, 2011). In venture obtainment, moral issues are about defilement or pay-off andclashing situation (Hassim et al, 2010).

\subsubsection{The pre-contract stage}

Jefferies and Kirk (2004) expressed that morals in the pre-contract stage is the place where the association is set. Other moral issues considered normal in the pre-contract stage incorporate specific tendering and also temporary workers guaranteeing knowledge they don't have. The delicate stage offers open doors for practices like specific treatment, pay off, and conspiracy though the construction stage may result to poor well-being conditions, concealing of low quality work and unjustifiable working hours for subcontractors (Tow and Loosemore, 2009). These incorporate withdrawal, offer cutting, spread estimating, pay of tendering expenses, and intrigue.Hassim et al (2010) categorised the critical factors that contribute to unethical conduct are as follow:

1. Economic downturn: Organisations are ready to do anything for to survive during the depression particularly to obtain projects or tenders from the public sectors.

2. National goal: several national policies and goals that require to be attained for it to be a developed nation, many projects ought to be finished at the particular time. They have led to strain the players of construction and result to unethical matters in procurement of project.

3. Leadership: Over half of the participants who took part in the study, felt that management is required as role model to enhance performance and demonstrate good leadership.

4. Non transparent selection procedure: One of the key reasons that ethical issues happen in preparation procurement is because of the selection procedure that is not transparent. For instance, government procurement and concession agreements result to sub-optimal outcomes.

5. Unsuccessful assessment of the procedure: The open tender procedure is one of the methods to alleviate the potential interest conflicts and to encourage project procurement's costefficiency.

6. Unsuccessfulness of professional ethics and procurement policy: Failure on behalf of expert staff to apply the level of consideration needed under the circumstance can bring about moral issues to happen in venture acquisition.

\subsection{Morals and nature of undertakings}

Human variables add to the vast majority of value related issues. The expert morals issues assume a basic part in quality-related issues in a construction venture (Hamzah et al, 2010). The industry has a reputation for poor administration and quality, a background marked by broken guarantees, a terrible wellbeing record, and sharp practice (Tow and Loosemore, 2009). Unscrupulous conduct by the industry of construction gatherings affects the venture's quality (Hamzah et al., 2010). Customers and temporary workers that are in the industry of construction will endeavour to procure ventures utilizing the ways including dishonest behaviour that overlooks honesty and profound quality. This is since they are prepared to do anything to persist amid the monetary subsidence. In view of this untrustworthy behaviour by the industry of construction gatherings, there is a major impact on the task quality (Hassim et al, 2010). Figure 1 demonstrates the importance of morals in task execution. Morals are considered as the fourth most crucial measurement in the venture. 


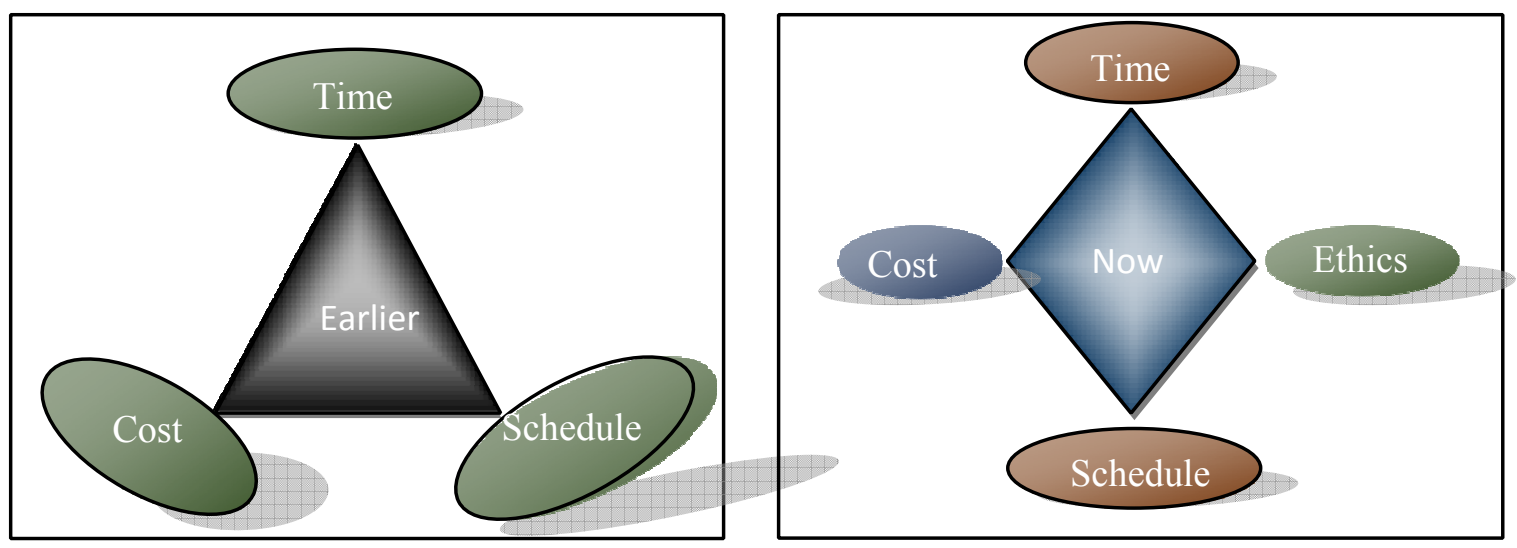

Fig 1 TQM triangle. Source: (Mishra and Mittal, 2011)

\subsection{Codes of conduct}

Codes are made to delegate obligation to both the key (proprietor, customer) and contending tenderers to have a harmony between what is right and what is judgment skills for each task. For the most part they are both pertinent to a few of the conventional sorts of contracting (e.g. single amount or outline and manufacture) and especially to tasks of a less standard nature or where risks included are scarcely or difficult to designate or decide (Ray et al., 1999). Codes of behaviours are left in the industry of construction to handle moral issues. In Australian industry of construction, tendering codes have been composed keeping in mind the end goal to handle moral issues like offer cutting, withdrawal, spread valuing, reward of tendering expenses and agreement" (CIOB, 2006). To an ever increasing extent, strict and general government standards are a truth of life in our general public. There are guidelines governing business, money, fabricating, security, training, the earth, research, medication, law, and government itself. In addition, as indicated by Masson (2011) moral conduct is in consistence with these moral qualities:

1. Honesty and confidence: work with trustworthiness and avoid lead liable to come about, by implication or straightforwardly in the double dealing of others.

2. Fairness and clarity: don't try to get an advantage which comes in a deceptive way or specifically from the out of line treatment of different people.

3. Reasonable reward: maintain a strategic distance from behaviour which is prone to bring about another gathering to be denied of a simply remunerate for their employment.

4. Reliability: maintaining abilities and offering benefits just in your general vicinity of capability.

5. Integrity: have regard for the hobbies of the general population, fundamentally people who will use or get an enthusiasm for the task later on.

6. Objectivity: perceive any conceivable irreconcilable situations and uncover the contention to any person who might be adversely influenced by it.

7. Responsibility: stay away from data and cautioning of issues within your insight which are of conceivable mischief to other people who may be adversely influenced by them. Cautioning should be given in enough time to allow making of viable move to maintain a strategic distance from damage. 
Jefferies and Kirk (2004) demonstrated that the NCOP (National Code Of Practice) for the construction industry, made nine key moral standards to ensure moral behaviour is seen at all anticipate stages by all gatherings. They are:

1. All tendering processes should be conducted with fairness and honesty at all industry levels.

2. Parties must conform to all lawful obligations.

3. Parties should not to take part in any conduct which gives one party an inappropriate benefit over another.

4. Tenderers should not to take part in any type of collusive practice and ought to be prepared to prove their probity.

5. Conditions of tendering ought to be the same for every tender on any specific project.

6. Clients should clearly identify their requirements in the tender documents and specify criteria for assessment.

7. Evaluation of tenders should be found on the tendering conditions and selection criteria described in the documents of tender.

8. Privacy of all information offered during tendering should be preserved.

Any group with a conflict of interest should announce it as soon as the group is aware of the conflict. This is first stage of unethical practices in any organisation including construction industry. Hence the findings from the literature suggested that the professionals from the construction industry should follow the moral qualities and tendering codes of practices to avoid the unethical practices. The next section describes about the research method adopted in this study.

\section{Research Methods}

This research has been conducted based on the quantitative research approach and the quantitative method is the core of deductive research philosophy. The main idea of deductive research is to reach a conclusion based on existing evidence. It calls for the collection of premises, which if validated, will contribute to forming a conclusion (Bloomberg, Cooper and Schindler, 2008). Quantitative research utilizes statistical analysis of numeric data, focusing on the issue has been identified from the research problem and relevant to research objectives (Matveev, 2002; Smith, 1988).

The selection of quantitative method for this research has several reasons, one of them is that, the research problem is very specific and it is regarding the unethical practices in the construction industry. Using the data, the study used statistical analysis to achieve the research objectives. Using quantitative method for such clear problems always prove to be efficient in data collection, analysis and having better validity of the research. The second reason in this research subjective judgment (use of qualitative method) would case biasness and higher inaccuracy, thus to eliminate subjective judgment quantitative method is a great technique. However, the main reason of selecting this method is the use of established statistical tools to achieve research objectives.

In this study, the research data related to unethical practices wascollected in the developing country where big investments are allocated in the construction industry. Hence, the survey was conducted in Saudi Arabia to uncover the factors that contributing in the unethical practices and its impact on product quality. Figure 2shows the systematic structure of research methods adopted in the study.

The study is based on the primary data which was collected using questionnaire design and conducting the construction industry survey via online tool (monkey survey). The study is the part of the dissertation study. The respondents were selected randomly to reduce biasness of the sample and 
the survey was targeted to the construction industry professionals mainly engaged with Government department such as ministry, local councils/municipalities, NGOs and consultant forms with aim of examining the current practices and views about unethical practices in the construction industry.

A total of 35 out of 60 responses were collected from the targeted respondents from construction professional from Saudi Arabiya. The collected data were analysed using statistical analysis tool called SPSS. The results from the study are presented in the form of tables and graphs followed by critical discussions with interpretation of practical significance in the construction industry.

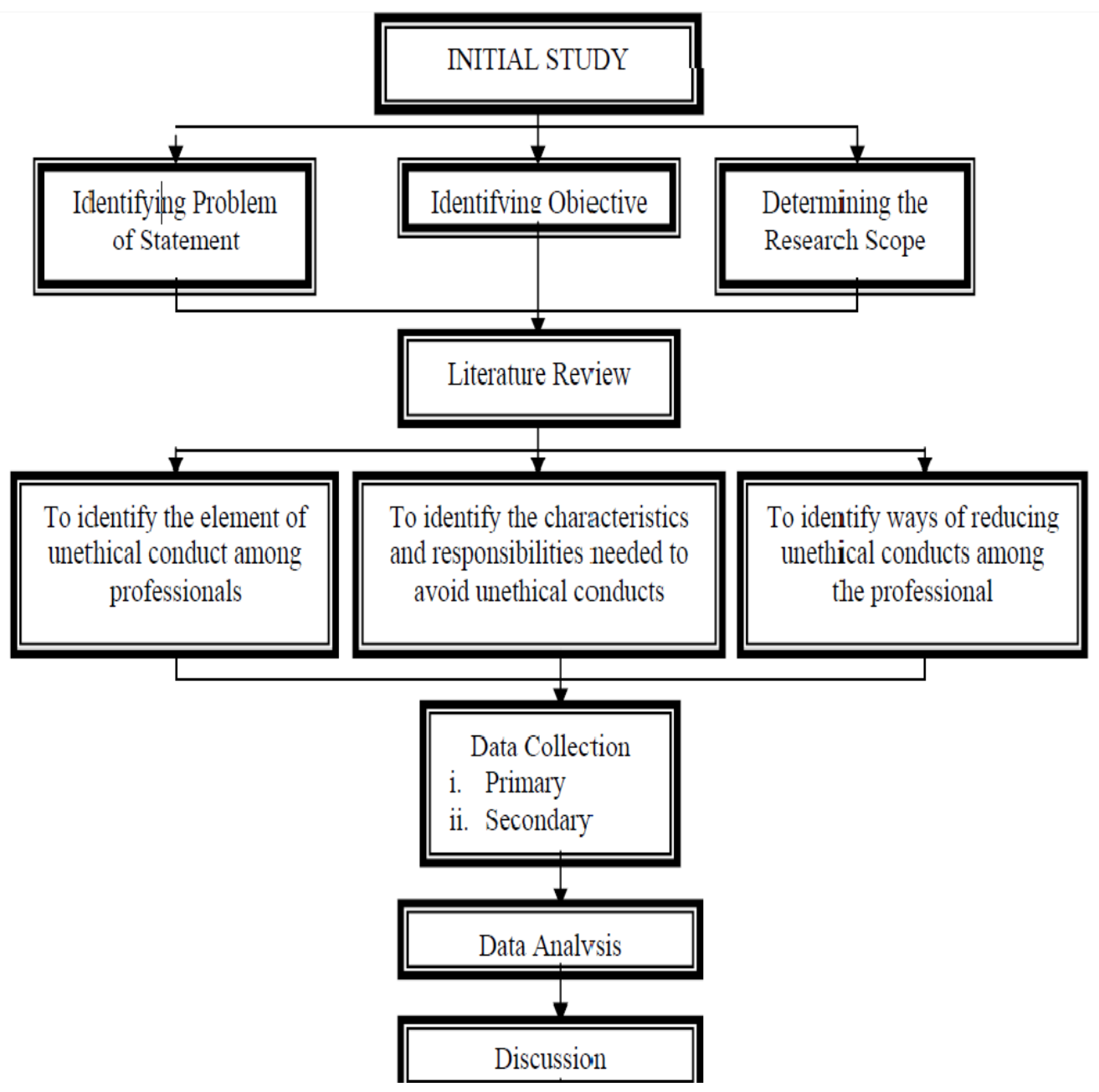

Fig 2 A systematic structure of the adopted research methods in this study

\section{Data Analysing and Results Discussion}

\subsection{General Profile of respondents}

The general profiles of the respondents/participants in the industry survey are summarised using frequency distribution and results are presented in Table 1with pie charts. The table shows the majority of the respondents from the consultant firms (42.9\%), and then in NGOs. It is also clear that a large group of respondents, who work in the construction industry, come from private organisations.Moving forward, among all the respondents, $40 \%$ were site engineers, and $25 \%$ were project managers, while another $20 \%$ were architects. However, surveyors are also present in the sample. This ensures the diversity of the responses from different professionals working in the 
construction industry of Saudi Arabia and they would sure have diverse points of view regarding the unethical practices, as they are involved in different levels and phases of construction work.

In addition to these, $40 \%$ of the sample respondents have less than 5 years' experience in the construction industries, while another $60 \%$ has more than 5 years of experience, this indicates as a whole there are more experienced respondents in the sample and therefore, the responses would have greater depth and real scenarios, due to their vast experience in this field. Among the respondents, $48.6 \%$ have a master's degree, while $31.4 \%$ have a bachelor's degree and only $20 \%$ have a doctorate degree. Considering this, it can be assumed that the respondents have greater qualification. Finally, majority of the respondents aged between 31-35 years (54.3\%), this indicates in the sample that moderately aged people would have greater in depth views regarding the construction industry.

Table 1 Demography profile of the respondents/participants in the survey

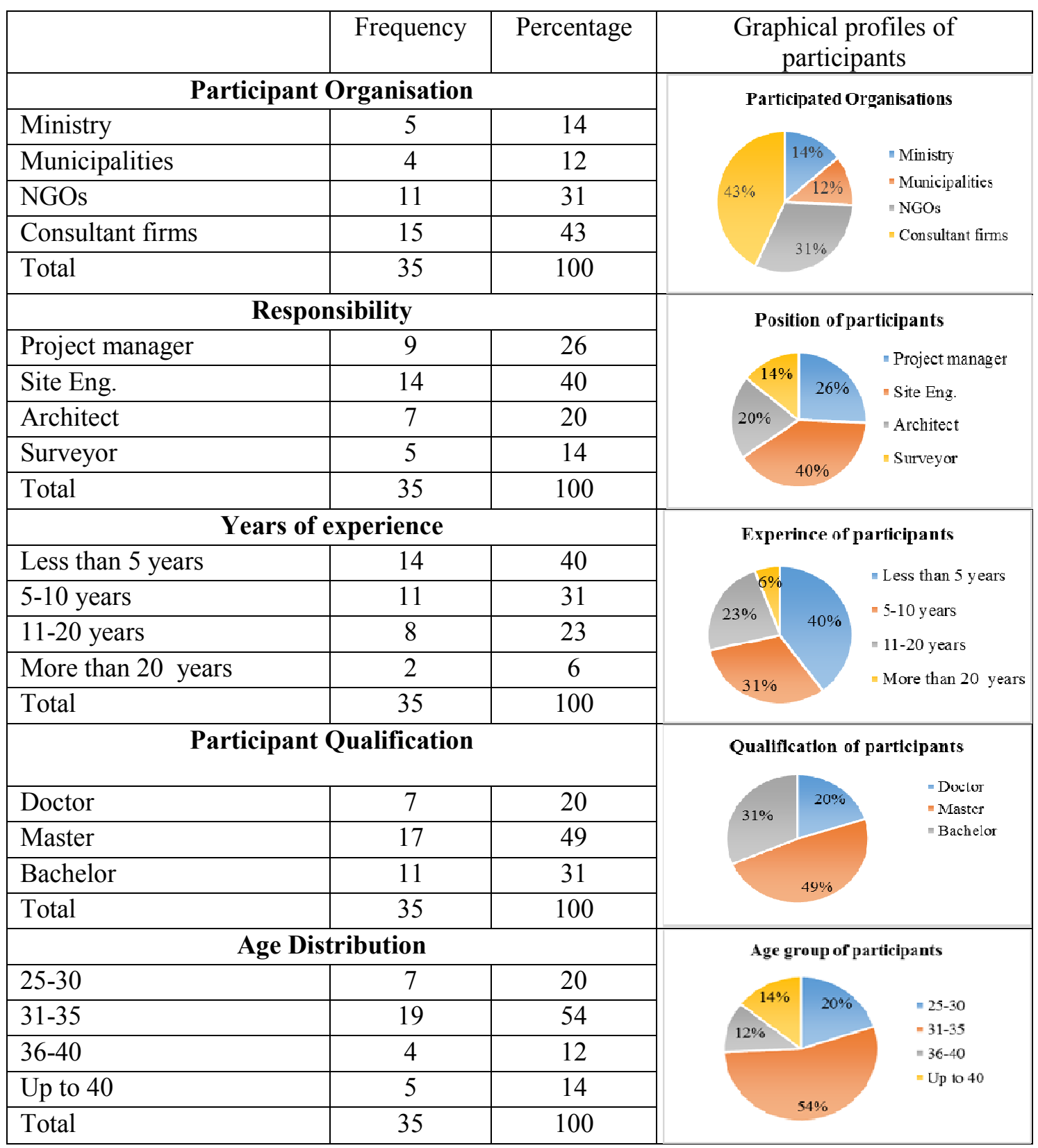




\subsection{Factors encourage unethical practices}

While doing the literature review, the research identified three broad domains of factors that are responsible for unethical practices in the construction industry of Saudi Arabia and they are owner/client related factors, contractor related factors and consultant related factors. In addition, the parameters included in these broad domains have been subjected to the factor analysis using SPSS to group them together and find the most relevant factors related to unethical conducts. These analysis have identified which factors are boosting the unethical practices in the construction industry.

\subsubsection{Owner related factors}

For owner factors, five items were identified and they were subjected to factor analysis. The factor analysis results listed below. Table 2 shows the KMO and Bartlett's Test of Sphericity. For the collected sample, $\mathrm{KMO}=.514$, this value is fairly expected to do factor analysis on the items; therefore factor analysis is appropriate for these data. Bartlett's test is highly significant (P-value < 0.001 ) and thus factor analysis is appropriate.

Table $2 \mathrm{KMO}$ and Bartlett's Test of Sphericity for owner related factors

\begin{tabular}{|c|c|l|}
\hline \multicolumn{3}{|c|}{ KMO and Bartlett's Test } \\
\hline Kaiser-Meyer-Olkin Measure of Sampling Adequacy. & .514 \\
\hline \multirow{2}{*}{$\begin{array}{c}\text { Bartlett's Test of } \\
\text { Sphericity }\end{array}$} & Approx. Chi-Square & 161.750 \\
\cline { 2 - 3 } & D f & 10 \\
\cline { 2 - 3 } & Sig. & .000 \\
\hline
\end{tabular}

Table 3 show initial eigenvalues reflect as a linear attribute before extraction. Prior to extraction, results showed five linear attributes within the data set. However, only two linear relations have the eigenvalues greater than one. The scree plot shown in Fig 3 also confirms that two components have eigenvalues greater than the acceptable value.

Table 3 Total variance for owner related factors

\begin{tabular}{|c|c|c|c|c|c|c|}
\hline \multicolumn{7}{|c|}{ Total Variance Explained } \\
\hline Component & \multicolumn{3}{|c|}{ Initial Eigenvalues } & Extraction Sums of Squared Loadings \\
\cline { 2 - 7 } & Total & $\begin{array}{c}\% \text { of } \\
\text { Variance }\end{array}$ & $\begin{array}{c}\text { Cumulative } \\
\%\end{array}$ & Total & $\begin{array}{c}\% \text { of } \\
\text { Variance }\end{array}$ & $\begin{array}{c}\text { Cumulative } \\
\%\end{array}$ \\
\hline 1 & 3.063 & 61.268 & 61.268 & 3.063 & 61.268 & 61.268 \\
\hline 2 & 1.037 & 20.733 & 82.002 & 1.037 & 20.733 & 82.002 \\
\hline 3 & .530 & 10.598 & 92.600 & & & \\
\hline 4 & .360 & 7.206 & 99.806 & & & \\
\hline 5 & .010 & .194 & 100.000 & & & \\
\hline \multicolumn{7}{|c|}{ Extraction Method: Principal Component } \\
Analysis.
\end{tabular}




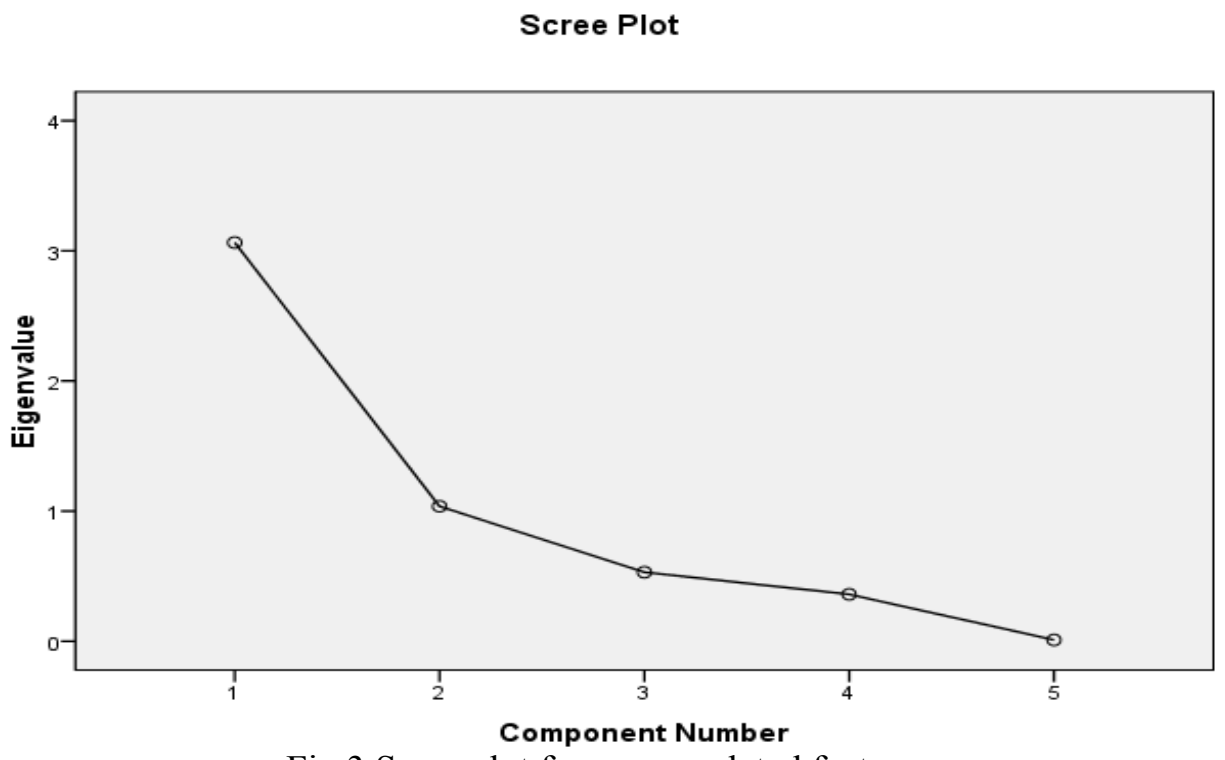

Fig 3 Scree plot for owner related factors.

These analyses gave us two component factors that are responsible for owner related factors leading towards unethical conduct. Among these two factors, factor 1 explained $61.26 \%$ of the total variance of the data, while the $20.733 \%$ variance was explained by factor 2 . Table 4 shows the component matrix that would explain the factors related to the unethical practices at owner level.

Table 4 Factors responsible for unethical practices at owner level

\begin{tabular}{|l|c|c|}
\hline \multicolumn{2}{|c|}{ Component Matrix } \\
\hline Items & 1 & 2 \\
\cline { 2 - 4 } & .970 & \\
\hline Awarding a tender to a contractor illegally & .867 & \\
\hline Delay payment & .845 & \\
\hline $\begin{array}{l}\text { Advertising a particular project land or categories for privet } \\
\text { purposes }\end{array}$ & & \\
\hline The owner would decreases the price of the tender & & .972 \\
\hline Extraction Method: Principal Component Analysis. & \\
\hline a. 2 components extracted. & \\
\hline
\end{tabular}

For the first component, at owner level, awarding a tender to a contractor illegally, delayed payment and advertising a particular project land or categories for privet purposes are found to be the most responsible for leading unethical practices. This is quite understandable seeing that with illegally awarding the project would surely involve corruption and the delay of payment for the project would made the owners of the project to work in unethical manner. However, advertisement for private purpose often focus particular firms and consultant, this lead to a potential unethical conduct in the construction process. Finally, the other factor only involves one item and that is the owner decreasing the price of the tender. This usually happens if the advertise is focused on the particular firms, then the owner know they would eventually get the contract, thus they intentionally reduce the price of the bid and this would lead to their unethical conducts. 


\subsubsection{Contractor related factors}

For contractor factors, seventeen items were identified and they were subjected to factor analysis. The factor analysis results listed below. Table 5 shows the KMO and Bartlett's Test of Sphericity. For the collected sample, $\mathrm{KMO}=.737$, this value is expected to do factor analysis on the items; therefore factor analysis is appropriate for these data. Bartlett's test is highly significant (P-value < 0.001 ), and thus factor analysis is appropriate.

Table $5 \mathrm{KMO}$ and Bartlett's Test of Sphericity for contractor related factors

\begin{tabular}{|l|c|c|}
\hline \multicolumn{2}{|l|}{ KMO and Bartlett's Test } \\
\hline Kaiser-Meyer-Olkin Measure of Sampling Adequacy. & .737 \\
\hline Bartlett's Test of Sphericity & Approx. Chi-Square & 253.284 \\
\cline { 2 - 3 } & df & 78 \\
\cline { 2 - 3 } & Sig. & .000 \\
\hline
\end{tabular}

Table 6 show the eigenvalues related to each linear attribute before extraction that has been presented after extraction and after rotation. Before extraction, SPSS identified thirteen linear attributes within the data set. However, only two linear relations have the eigenvalues greater than one. The scree plot, which is shown in Fig 4 also confirms that two components have eigenvalues greater than the acceptable value.

Table 6 Total variance for contractor related factors

\begin{tabular}{|c|c|c|c|c|c|c|}
\hline \multicolumn{7}{|c|}{ Total Variance Explained } \\
\hline Component & \multicolumn{7}{|c|}{ Initial Eigenvalues } & \multicolumn{2}{c|}{$\begin{array}{c}\text { Extraction Sums of Squared } \\
\text { Loadings }\end{array}$} \\
\cline { 2 - 7 } & Total & $\begin{array}{c}\text { \% of } \\
\text { Variance }\end{array}$ & $\begin{array}{c}\text { Cumulative } \\
\%\end{array}$ & Total & $\begin{array}{c}\% \text { of } \\
\text { Variance }\end{array}$ & $\begin{array}{c}\text { Cumulative } \\
\%\end{array}$ \\
\hline 1 & 4.553 & 35.025 & 35.025 & 4.553 & 35.025 & 35.025 \\
\hline 2 & 3.609 & 27.763 & 62.788 & 3.609 & 27.763 & 62.788 \\
\hline 3 & .957 & 7.363 & 70.150 & & & \\
\hline 4 & .872 & 6.710 & 76.860 & & & \\
\hline 5 & .652 & 5.012 & 81.872 & & & \\
\hline 6 & .522 & 4.015 & 85.887 & & & \\
\hline 7 & .438 & 3.372 & 89.259 & & & \\
\hline 8 & .384 & 2.954 & 92.213 & & & \\
\hline 9 & .321 & 2.468 & 94.681 & & & \\
\hline 10 & .301 & 2.318 & 96.999 & & & \\
\hline 11 & .170 & 1.305 & 98.304 & & & \\
\hline 12 & .127 & .974 & 99.278 & & & \\
\hline 13 & .094 & .722 & 100.000 & & & \\
\hline $\begin{array}{l}\text { Extraction } \\
\text { Analysis. }\end{array}$ & Method: & Principal & Component & & & \\
\hline
\end{tabular}

All these analyses gave us two components that are responsible for contractor related factors leading towards unethical conducts. Among these two factors, factor 1 explaining $35.02 \%$ of the total variance of the data, while the $27.76 \%$ variance is explained by factor 2 . Now if we look at table 7 , the component matrix would explain the factors related to the unethical practices for the contractors. 


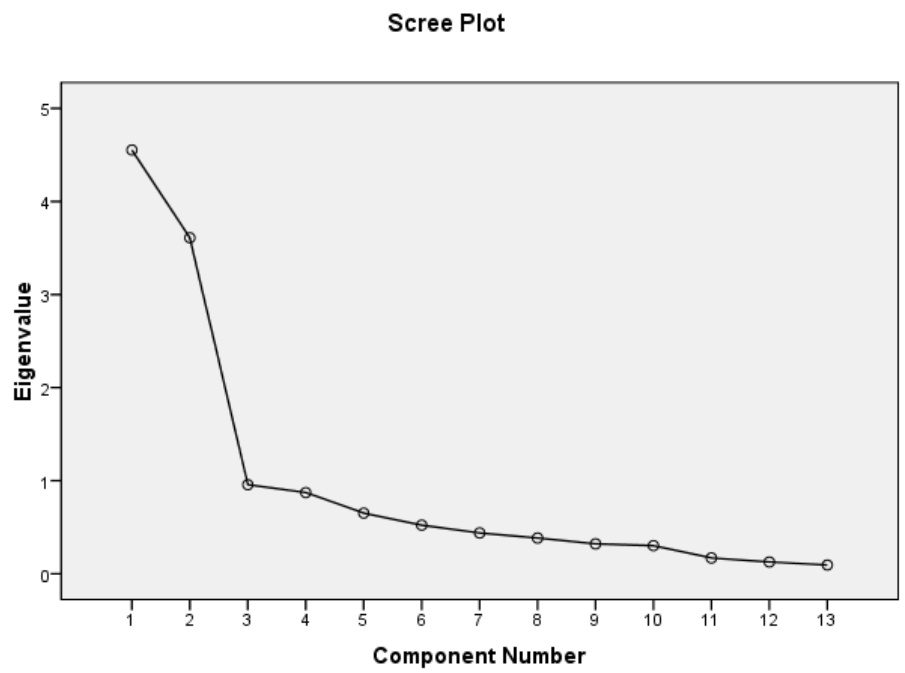

Fig 4 Scree plot for contractor related factors.

Table 7 presents the items under the extracted factors have been listed. For the $1^{\text {st }}$ factor, contractor's characteristic regarding the bidding process have been grouped. For this factor, collusive bidding, over billing, bid cutting, bid rigging and eloping from duties are found to be most influential to unethical conduct in the process of construction activities.

Table 7 Factors responsible for unethical practices at contractor level

\begin{tabular}{|l|c|c|}
\hline \multicolumn{3}{|c|}{ Component Matrix } \\
\hline \multicolumn{1}{|c|}{ Items } & \multicolumn{2}{|c|}{ Component } \\
\cline { 2 - 3 } & 1 & 2 \\
\hline $\begin{array}{l}\text { Agree of one contractor to withdraw an offer he has made in } \\
\text { exchange for money or other benefits }\end{array}$ & .850 & \\
\hline Under bidding, Bid cutting, Bid shopping and Bid rigging & .844 & \\
\hline Withdrawal of tender & .807 & .746 \\
\hline Overbilling. & .715 & \\
\hline $\begin{array}{l}\text { Employers attempting to force their employees to do unethical } \\
\text { conduct }\end{array}$ & .554 & \\
\hline Contractor's eloping from their duties after delivering the project & .753 \\
\hline $\begin{array}{l}\text { Fraud like illogical request for time extensions or Compromise on } \\
\text { quality or increase the cost }\end{array}$ & & .720 \\
\hline $\begin{array}{l}\text { Fraud in determining the amount of the item in the table of } \\
\text { quantities for financial purposes }\end{array}$ & & -.710 \\
\hline $\begin{array}{l}\text { Contractor's professional don't disposed waste, in suitable and } \\
\text { safe ways which is friendly with the environment }\end{array}$ & .677 \\
\hline $\begin{array}{l}\text { Professionals don't hold paramount the safety, health and welfare } \\
\text { of the labour inside the work site }\end{array}$ & & .641 \\
\hline $\begin{array}{l}\text { Fraud in the preparation of the daily report for the purpose of } \\
\text { compensating later }\end{array}$ & & -.618 \\
\hline $\begin{array}{l}\text { Contractors agree to take money in order not to tender for a } \\
\text { contract }\end{array}$ & & .602 \\
\hline $\begin{array}{l}\text { The engineers don't recognize the safety of public when } \\
\text { considering personal/ organisational benefits }\end{array}$ & & \\
\hline Extraction Method: Principal Component Analysis. & \\
\hline
\end{tabular}


Exchange of money is an encouraging aspect for many consultants, if they got money due to not bidding or withdrawing the bid, it is obvious that they would allow the firm to offer the bribe for their own benefits. Additionally, under bidding, bid cutting, bid shopping and bid rigging are very common practices that encourage greater benefit for particular firm or group of firms, thus the potential to benefit encourage unethical conduct in the construction industry. For the second component in this case, fraud-like and illogical requests for time extensions, compromise on quality, cost increase, fraud in determining the amount of the item in the table of quantities for financial purposes and fraud in the preparation of the daily report for the purpose of compensating later are grouped together. This indicates that the contractors would partake in unethical practices for time extension, financial anomalies and daily reporting, which all would lead to various benefits for the firms. These aspects encourage the contractors to resort to unethical conduct to benefit their own companies. In addition to these, lack of concern for environment, safety also lead toward unethical conducts in the construction process.

\subsubsection{Consultant related factors}

For consultant factors, seventeen items were identified and they were subjected to factor analysis. The factor analysis results listed below. Here, Table 8 shows the KMO and Bartlett's Test of Sphericity. For the collected sample, $\mathrm{KMO}=.48$, this value is near to the expected level to do factor analysis on the items. However, Bartlett's test is highly significant (P-value $<0.001$ ), and thus factor analysis is appropriate.

Table $8 \mathrm{KMO}$ and Bartlett's Test of Sphericity for consultant related factors

\begin{tabular}{|c|c|c|}
\hline \multicolumn{3}{|c|}{ KMO and Bartlett's Test } \\
\hline \multicolumn{2}{|c|}{$\begin{array}{c}\text { Kaiser-Meyer-Olkin Measure of Sampling } \\
\text { Adequacy. }\end{array}$} & .480 \\
\hline $\begin{array}{c}\text { Bartlett's Test of } \\
\text { Sphericity }\end{array}$ & Approx. Chi-Square & 80.476 \\
\cline { 2 - 3 } & df & 6 \\
\cline { 2 - 3 } & Sig. & .000 \\
\hline
\end{tabular}

Table 9 presents eigenvalues related to each linear attribute before extraction has been presented, after extraction and after rotation. Before extraction, SPSS has identified 4 linear attributes within the data set. However, among them only two linear relations have the eigenvalues greater than one. The scree plot (Figure 5) also confirms that, two components have eigenvalues greater than the acceptable value.

Table 9 Total variance for consultant related factors

\begin{tabular}{|c|c|c|c|c|c|c|}
\hline \multirow{2}{*}{ Component } & \multicolumn{5}{|c|}{ Total Variance Explained } \\
\cline { 2 - 7 } & Total & $\begin{array}{c}\text { \% of } \\
\text { Variance }\end{array}$ & $\begin{array}{c}\text { Cumulative } \\
\%\end{array}$ & Total & $\begin{array}{c}\text { Ex of } \\
\text { Variance } \\
\text { Loadings }\end{array}$ & $\begin{array}{c}\text { Cumulative } \\
\%\end{array}$ \\
\hline & 2.417 & 60.427 & 60.427 & 2.417 & 60.427 & 60.427 \\
\hline 2 & 1.212 & 30.292 & 90.720 & 1.212 & 30.292 & 90.720 \\
\hline 3 & .270 & 6.761 & 97.481 & & & \\
\hline 4 & .101 & 2.519 & 100.000 & & & \\
\hline Extraction Method: Principal Component Analysis. & & & \\
\hline
\end{tabular}




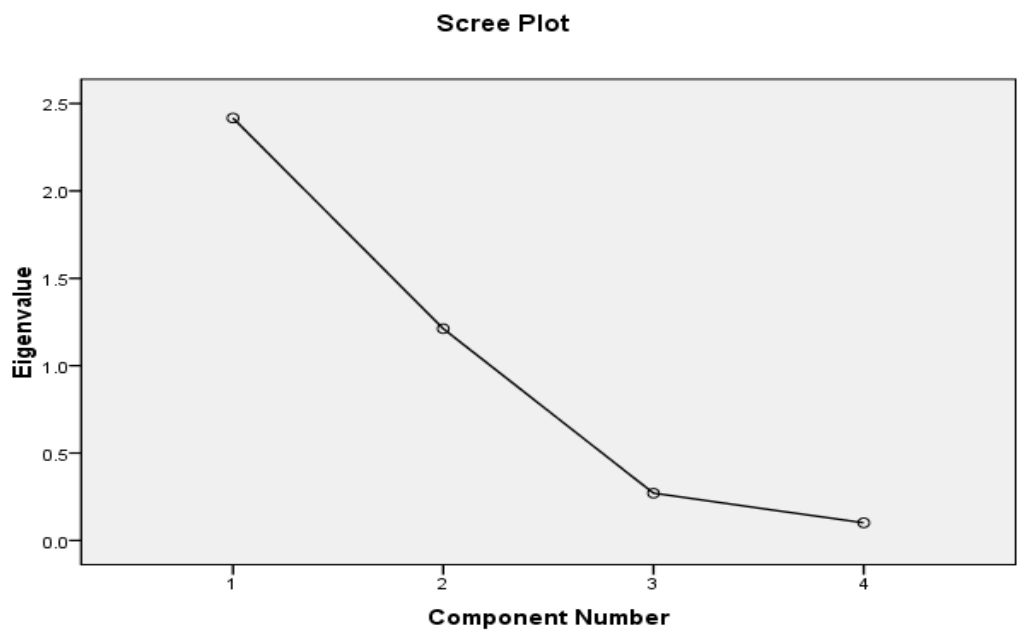

Fig 5 Scree plot for consultant related factors.

Table 10 Factors responsible for unethical practices at consultant level

\begin{tabular}{|l|c|c|}
\hline \multicolumn{3}{|c|}{ Component Matrix } \\
\hline $\begin{array}{l}\text { Imposing of heavy and unfair fines on the } \\
\text { contractor to attract his bribery }\end{array}$ & .878 & 2 \\
\hline Lack of supervision & .873 & \\
\hline Lack of consultant experience & .864 & \\
\hline Accepting bribery from the contractor & & .901 \\
\hline Extraction Method: Principal Component Analysis. \\
\hline
\end{tabular}

Table 10 illustrates that for component one, lack of supervision, lack of experience and pressure of the consultant lead towards unethical practices for the consultant. It is quite obvious that without supervision of the authority, the consultant have the opportunity to create pressure on the contractors imposing of heavy and unfair fines to fulfil his bribery requests and the inexperienced contractors are the victims of such unethical conduct. In addition to this, the consultants take bribes from the constructors which are a major component derived from the greed of the consultant, which in turn leads to unethical practices.

\subsection{Most common forms of unethical practices}

There are several forms of unethical practices and the elements involved are also diverse. Doing unethical conducts lead to take some kind of favours or benefits. Among these, the elements or forms of exchanging the benefits can be different. Some can be in financial terms using gifts or money, while others can be having conflict of interest, nepotism, favouritism, hospitality and so on. In this study, the respondents were asked what kind of form they think are the most common for the outcome of unethical practices and they provided diverse answers. In order to check which form is most common, a non-parametric chi-square test has been conduct among the answer options. Here, if all the forms are same, and they have no difference, then the expected and observed count for all of them would be the same. However, Table 11 shows the variation in responses about the unethical practices. 
Table 11 Variation in the response for the common forms of unethical practices

\begin{tabular}{|l|c|c|c|}
\hline \multicolumn{4}{|c|}{ Common form of unethical practices (contingency table) } \\
\hline $\begin{array}{l}\text { Elements of unethical } \\
\text { conducts }\end{array}$ & $\begin{array}{c}\text { Observed } \\
\mathrm{N}\end{array}$ & Expected N & Residual \\
\hline Gifts & 6 & 4.4 & 1.6 \\
\hline Hospitality & 3 & 4.4 & -1.4 \\
\hline Bribes and inducements & 15 & 4.4 & 10.6 \\
\hline Conflict of interest & 5 & 4.4 & .6 \\
\hline Nepotism and social & 2 & 4.4 & -2.4 \\
\hline Favouritism & 2 & 4.4 & -2.4 \\
\hline $\begin{array}{l}\text { Political andiour } \\
\text { behaviour }\end{array}$ & 1 & 4.4 & -3.4 \\
\hline Health and safety & 35 & & -3.4 \\
\hline Total & & & \\
\hline
\end{tabular}

Table 12 Test result for common forms of unethical practices

\begin{tabular}{|l|c|}
\hline \multicolumn{2}{|c|}{ Test Statistics } \\
\hline & Common form unethical \\
\hline Chi-Square & 34.714 \\
\hline $\mathrm{df}$ & 7 \\
\hline Asymp. Sig. [P-value] & .000 \\
\hline & \\
\hline
\end{tabular}

In this case, Table 12 confirms that there is statistically a significant difference in the responses for common forms of unethical practices that involves exchanges of different financial or personal benefits (Chi-square $=34.71, \mathrm{df}=7, \mathrm{p}<0.05$ ). Now if we look at Table 11, it is clear from the residual value that taking bribes and inducements, are the most common practices involved in unethical conduct, while the second common form is taking any kind of gifts and finally the third common from is having a benefit from conflicts of interest in Saudi construction industry. It is well known that bribes and gifts are often presented in the bidding process of construction activities to gain the project, but even personal or professional conflicts of interest can be deemed as common unethical practices.

\subsection{Stage of the construction process more susceptible to unethical practices}

In any construction project there are several stages which may include expression of interest, proposal, bidding, awarding, intervention, monitoring and evaluation. However, as a whole for construction industry these stages can be grouped under two broad categories, before awarding the project and after awarding the project. Owners, contractors, and consultant all are involved in the both before and after awarding phases, yet their practices of unethical conduct are different at different stages. In this research, the items related to unethical practices grouped under these broad categories and the responses are subjected to a test, (Mann-Whitney $U$ ) to investigate if any of this stage is more susceptible to unethical practices. This is a non-parametric test that compares the mean values between the groups and shows the statistical significance of the mean ranks. The mean rank for before and after awarding the project is presented in Table 13. 
Table 13 Mean rank for Stage when the unethical conducts take palace

\begin{tabular}{|l|c|c|c|}
\hline & Stage & N & Mean Rank \\
\hline $\begin{array}{l}\text { Stage when the } \\
\text { unethical conduct take } \\
\text { palace }\end{array}$ & Before Awarding & 35 & 52.99 \\
\cline { 2 - 4 } & After Awarding & 35 & 18.01 \\
\cline { 2 - 4 } & Total & 70 & \\
\hline
\end{tabular}

Table 14, confirms that there is significant difference in the mean rank before and after awarding the projects as the $\mathrm{p}<0.05$, in this case the Mann-Whitney $\mathrm{U}=0.50, \mathrm{P}=0.000$, indicating significance of the test.

Table 14 Test result for Stage when the unethical conducts take palace

\begin{tabular}{|l|c|}
\hline \multicolumn{2}{|c|}{ Test Statistics' } \\
\hline & Related test scores \\
\hline Mann-Whitney U & .500 \\
\hline Z & -7.225 \\
\hline Asymp. Sig. (2-tailed) [p-value] & .000 \\
\hline a. Grouping Variable: Stage \\
\hline
\end{tabular}

As per the mean rank shown in Table 13, before awarding the project, majority of the unethical conduct takes place (see Table 14) as per the respondents. According to them, bidding process involves lots of irregularities and the owners take several steps of bribing and collusion to get the project. At this stage, they manipulate the people responsible for the awarding process prior to awarding the project. However, the after awarding phase also involves unethical conduct such as: lack of consideration for people and the environment as well as error in monitoring processes. However, these are less susceptible when compared to the phase prior to awarding, so it can be confirmed that the before awarding the projects phase is more susceptible to unethical practices.

\subsection{Strategies to discourage minimize and rein in unethical practice}

The factors, forms and stages of unethical conduct has been identified, now the research focused on findings strategies that would discourage, minimise, and restraint in unethical practice in the construction industry (see Table 15).

Table 15 List of preventive measures of unethical practices

\begin{tabular}{|c|c|c|c|c|c|c|c|}
\hline $\begin{array}{c}\text { Reduce unethical } \\
\text { methods }\end{array}$ & $\begin{array}{c}\text { Strongly } \\
\text { Agree }\end{array}$ & Agree & Neither & $\begin{array}{c}\text { Strongly } \\
\text { Disagree }\end{array}$ & Disagree & $\begin{array}{c}\text { Total \% } \\
\text { Agree }\end{array}$ & $\begin{array}{c}\text { Total \% } \\
\text { Disagree }\end{array}$ \\
\hline $\begin{array}{c}\text { Avoid conflict of } \\
\text { interest }\end{array}$ & 7 & 17 & 9 & 4 & 0 & 68.6 & 05.7 \\
\hline $\begin{array}{c}\text { Motivation and } \\
\text { training }\end{array}$ & 5 & 3 & 17 & 7 & 3 & 22.9 & 28.6 \\
\hline $\begin{array}{c}\text { Have good company } \\
\text { value matched with } \\
\text { employee }\end{array}$ & 6 & 3 & 13 & 10 & 3 & 25.7 & 37.2 \\
\hline $\begin{array}{c}\text { Benefits to employees } \\
\text { and increments }\end{array}$ & 19 & 16 & 0 & 0 & 0 & 100 & 0 \\
\hline Regular Monitoring & 13 & 11 & 11 & 0 & 0 & 68.6 & 0 \\
\hline Proper Supervision & 12 & 14 & 5 & 2 & 2 & 74.3 & 11.4 \\
\hline
\end{tabular}


In this case, the totally agree and disagree have been measured based on strongly agree, and agree to the statement or strongly disagree and disagree to the statement (see Table 15). The analysis found that among several strategies, the respondents agreed $100 \%$ that benefits to the employees and increments for their salaries often encourage them to stop unethical activities. This means with increased benefits, the people involved will reduce the unethical conducts. Furthermore, regular monitoring and avoiding the conflict of interest found $68.6 \%$ positive acceptance for reducing the unethical conducts. Proper supervision $(74.3 \%)$ also has been found to have greater impact on reducing the unethical conduct in the construction activities.

\subsection{General measures of ethics and their relation with profitability}

In addition to unethical conduct related questions, the respondents were also asked if they have read the ethics code of Saudi council of engineers and (54.3\%) of the respondent's state that yes they have read the ethics code while the other $45.7 \%$ said no (see Table 16). This indicates, a vast majority of the professional yet lack knowledge on the ethics code.

Table 16 "Engineer's Ethics Code" reading status

\begin{tabular}{|l|c|c|c|c|c|}
\hline \multicolumn{6}{|c|}{ Have you read "Engineer's Ethics Code" published by Saudi Council of } \\
Engineers?
\end{tabular}

In addition to ethics code, the respondents were also asked about the impact of ethical behaviour on long-term profitability and $88.6 \%$ of the respondents agreed that they found a positive relationship between ethical behaviour and long-term profitability for the company.

Table 17 Impact of ethical behaviour

Is there a positive relationship between ethical behaviour and long- term profitability of the company?

\begin{tabular}{|c|c|c|c|c|c|}
\hline \multicolumn{2}{|c|}{} & Frequency & Percentage & $\begin{array}{c}\text { Valid } \\
\text { Percentage }\end{array}$ & $\begin{array}{c}\text { Cumulative } \\
\text { Percentage }\end{array}$ \\
\hline \multirow{2}{*}{ Valid } & Yes & 31 & 88.6 & 88.6 & 88.6 \\
\cline { 2 - 6 } & No & 4 & 11.4 & 11.4 & 100.0 \\
\cline { 2 - 6 } & Total & 35 & 100.0 & 100.0 & \\
\hline
\end{tabular}

As presented in Table17, it is obvious that people would find positive impact of ethical conduct as it relates to profitability. With positive ethical behaviour the reputation of the company become more transparent and acceptable, this subsequently will lead to better profits in the future. Finally, all the respondents agreed that if they were in a position of a decision maker in the organisation and he/she has two contractors having the same experience, financial ability, managerial ability, repetition and work history, they would not send Invitation-To-Bid (ITB) to the contractor who is close relative, 
friend or tribe-member. It is obvious, none would agree on doing any favouritism or nepotism on a public project.

\section{Conclusions and Recommendations}

It is concluded that there are several factors, encouraging the unethical practices in the construction industry. From client/owner aspects, illegal action and imposing pressure on project manager, delay in payment processes are key factors that contribute in the unethical practices. While, under bidding, bid cutting, bid shopping and bid rigging, over billing, fraud activities and illogical demands are key contributors of unethical practices from the contractor prospective but from the consultant prospective,lack of supervision, monitoring and taking bribes from contractors are found to be encouraging factors for unethical conductin the construction industry. Moreover, the common elements under unethical conduct also include bribes, gifts and conflicts of interest. In the form of bribes, the people partaking in unethical practice take monetary benefits. Gifts are often promoted as a common way of transferring the benefits of unethical conduct. Last but not the least, there is the element known as conflicts of interest is one of root cause of such practices. The paperalso revealed that unethical practices takes place both prior to and after the construction project awarding. However, it is found that major unethical practices in the construction industry take place in the tendering stage or prior to awarding a project.Since, a vast majority of professionals are ignorant to the ethics code, promoting ethics code and motivating them with greater company values might help to reduce unethical practices. Thepaperalso highlighted that the issues like benefits to employees, avoiding conflicts of interest, strict monitoring and proper supervision can be some effective ways to discourage and minimise the unethical practices among the stakeholders in the construction industry.

\section{Limitations}

The study islimited to small number of samples and the cross-sectional design so the long term effect cannot be fully addressed in this study, just like how the way people perceive unethical practices over a long term cannot be placed. Qualitative and inductive approaches can complement these findings; hence, the lack of a qualitative method is another limitation of this study. Last but not the least, the study was conducted using a small sample of respondents due to lack of resources. The use of more samples with complex multivariate analytical methods would provide better understanding of the research findings, as well as add more validity and reliability of the research outcomes.

\section{Recommendations for preventive measures}

Based on several strategies pointed out by the respondents and their measures of ethics and their relation with profitability, the study has formulated the following recommendations to reduce the effects of the critical factors that lead to unethical conducts;

1. Increase the benefits for the employees and if possible, provide shares from the overall profit, these would keep them happy considering the financial aspects. A decent appraisal for employee work willresult the changing behaviour and increase their moral values to keep them ethical in their professional practices.

2. Avoid conflicts of interest by managing the projects under one authority and encouraging the reduction of personal conflict of interest between the employees and company.This will promote greater values for the companies in line with the personal values of the employees. 
3. Conduct the regular monitoring systems at the different stages of the project and appoint independent monitoring bodies for effective and regular auditing of financial for company.

4. Ensure punishment for unethical activities at different stages of the construction activities.

5. Promote ethics code and awareness regarding the values of ethical behaviour for the overall good of the construction industries at different forums and media platform.

\section{Recommendations for future studies}

- Design a study that includes both quantitative and qualitative methods by ensuring a triangulation process to differentiate findings from one another.

- $\quad$ Take a larger sample size from different areas around the countrythat involved in the construction industry to make sure the geographic diversity of the data.

- To explore the underlying reasons behind the unethical conducts in the construction industry.

\section{References}

1. Alsweity A Y., "Unethical conduct among professionals in the construction industry", Master's Thesis, the Islamic University of Gaza, (2013)

2. Azhar S, Selph J and Maqsood T., "Unethical business practices and corruption in international construction:" A survey of American contractors working overseas. In 6th Nordic Conference on Construction Economics and Organisation (p. 457) (2011).

3. Bloomberg, B., Cooper, D.R. and Schindler, P.S., "Business research methods" (2nd European.) 2008.

4. CIOB, "Bringing them home, Report of the corruption in the UK construction industry", UK (2006).

5. Degn E and Miller K., Bid shopping, "Journal of construction education”, Vol. 8, No. 1, pp. 47- 55, (2003).

6. Ehsan N, Anwar S and Talha M., "Professional ethics in the construction industry of Pakistan”, World congress on engineering, 2176(1): pp729-733 (2009).

7. Eyaa S and Oluka P., "Explaining non-compliance in public procurement in Uganda", International journal of business and social science, Vol.2, No.11, pp35-44. Fellows, R. 2003. Professionalism

8. Gogulski, P., "Owners Delay of Payment on Change Orders Causes Serious Problems". [Online] Experts.com. Available at: http://www.experts.com/Articles/Owners-DelayPayment-Change-Orders-Causes-Serious-Problems-By-Paul-Gogulski [Accessed 3 Feb. 2017].

9. Hamzah A, Wang C and Yap X., "How professional ethics impact construction quality: perception and evidence in a fast developing economy", Scientific research and essays, 5(23): pp 3742-3749(2010) 
10. Hassim A, Kajewski S and Trigunarsyah B, "Factors contributing to ethical issues in project procurement planning: a case study in Malaysia", Proceedings of the 8th international conference on construction and real estate management, Royal on the Park hotel, Brisbane, Queensland, (2010).

11. Ho C M, "Ethics management for the construction industry, Engineering, construction and architectural management”, 18(5): pp 516-537(2011).

12. JefferiesMand KirkA, "Ethical behaviour in the construction procurement process". Globalisation and Construction, p.941, (2004).

13. Mason J, "Ethics in the construction industry: The prospects for a single professional code International journal of law in the built environment”, 1 (3) pp194-205(2009).

14. Matveev, A V, "The advantages of employing quantitative and qualitative methods in intercultural research: Practical implications from the study of the perceptions of intercultural communication competence by American \& Russian managers." Bulletin of Russian Communication Association of Communication and Applied Communication, Vol.1, pp59-67, (2002).

15. Miller, "Improve poor ethics in construction, set consequences", Colorado real estate journal, (2011).

16. Mishra, Pand Mitall, D “An ethical approach towards sustainable project success”, Procedia - social and behavioural sciences 25: pp 338-344(2011).

17. Ogachi, J, “The status of the procurement profession in Kenya: baseline indicators", Journal of the association of professional societies in East Africa, Vol. 3, pp.1-34(2011).

18. Olusegun A, Benson O, Esther A and Michael A, "Corruption in the construction industry of Nigeria: causes and solutions", Journal of emerging trends in economics and management sciences, Vol. 2, No. 3, pp156-159(2011).

19. Oyewobi L, Ganiyu B, Oke A, Ola-Awo A and Shittu A, "Determinants of unethical performance in Nigerian construction industry", Journal of sustainable development, Vol. 4, No. 4, pp 175-182(2011).

20. Patrick, Z, "Strategies for minimizing corruption in the construction industry in China", Journal of construction in developing countries, Vol. 11, No. 2, pp. 15-29(2006).

21. Pearl R, Bowen P, Makanjee N, Akintoye, A and Evans, K, "Professional Ethics in theSouth African Construction Industry - A Pilot Study", Journal of Construction Managementand Economics Volume 25, Issue 6, pp 631 - 648 (2007).

22. Rahman, A B A, "Unethical conduct among professionals in the construction industry", Doctoral dissertation report, University Teknologi Malaysia (2008). 
23. Ray R, Hornibrook J and Skitmore, R, "Ethics in tendering: a survey of Australian opinion and practice, Construction management and economics", Vol. 17, Issue. 2, pp. 139153(1999).

24. Sinha S, Randolph T and Kulka, J, "Integrating ethics into engineering design of construction process", American society for engineering education annual conference \& exposition (2004).

25. Smith, M J, "Contemporary communication research methods". Wadsworth Publishing Company (1988).

26. Tow D and Loosemore $\mathrm{M}$, "Corporate ethics in the construction and engineering industry", Journal of Legal Affairs and Dispute Resolution in Engineering and Construction, 1(3), pp.122-129(2009).

27. Uff J, "Duties on the legal fringe: ethics in construction law", Fourth Public lecture delivered at King's Collage, London (2003).

28. Vee C and Skitmore C, "Professional ethics in the construction industry", Engineering, Construction and Architectural Management, 10(2), pp.117-127 (2003).

29. Wulf, W A, "Engineering ethics and society. Technology in Society", 26(2), pp.385-390 (2004). 